Anita Abramowska-Kmon

Instytut Statystyki i Demografii

Szkoła Główna Handlowa w Warszawie

aabram@sgh.waw.pl

\title{
DETERMINANTY SPRAWOWANIA OPIEKI NAD STARSZYMI RODZICAMI W POLSCE W ŚWIETLE DANYCH BADANIA GGS-PL
}

\section{WSTĘP}

Jednym spośród szeroko dyskutowanych skutków starzenia się ludności jest wzrost liczby osób starszych wymagających wsparcia i tym samym zwiększenie zapotrzebowania na różnego rodzaju usługi opiekuńcze (zarówno formalne, jak i nieformalne ${ }^{1}$ ) (por. np. Abramowska-Kmon 2011, de Jong-Gierveld i van Solinge 1995, Doblhammer i Ziegler 2006, Vaupel i von Kistowski 2008). Ponadto na skutek zmniejszenia podaży nieformalnych usług opiekuńczych, na którą wpływa m.in. liczba potencjalnych opiekunów nieformalnych i ich dostępność (bliskie zamieszkiwanie, obecność na rynku pracy) (por. np. Wolf i Ballal 2006) zapotrzebowanie na opiekę nad osobami starszymi może okazać się jeszcze większe. Osoby starsze w Polsce w zdecydowanej większości otrzymują pomoc w ramach nieformalnych sieci wsparcia, głównie sprawowaną przez kobiety - żony, córki, synowe i inne krewne (por. np. Pączkowska 2002, Bień 2006, Golinowska 2006, Szczerbińska 2006, Czekanowski 2002, 2006, Grotowska-Leder 2008, Wóycicka 2009, Abramowska-Kmon i Kotowska 2009, Abramowska-Kmon 2011).

W tym kontekście wiele miejsca w literaturze naukowej poświęca się kwestii sprawowania opieki nad starszymi rodzicami przez dorosłe dzieci. Wyniki analiz pokazują, że na sprawowanie opieki nad niesamodzielnymi rodzicami wpływają zarówno charakterystyki indywidualne dorosłych dzieci-opiekunów (płeć, wiek, poziom wykształcenia, jak i cechy rodziców (wiek, stan zdrowia) (por. np. Albuqu-

1 Źródłem opieki nieformalnej są przede wszystkim członkowie rodziny (z tego samego lub spoza gospodarstwa domowego), a także inni krewni, przyjaciele lub sąsiedzi świadczący pomoc nieodpłatnie. Z kolei opieka formalna jest dostarczana przez organizacje publiczne, charytatywne i komercyjne. Granice między opieką formalną i nieformalną nie są wyraźne (por. Abramowska-Kmon 2011). 
erque 2014, Ogg i Renaut 2006). Ponadto niezwykle ważną determinantą jest jakość relacji rodzice-dzieci, a także opinie na temat odpowiedzialności dzieci za opiekę nad starszymi rodzicami.

W związku z tym głównym celem artykułu jest wskazanie indywidualnych determinant sprawowania opieki nad starszymi rodzicami przez osoby w wieku 45-69 lat. Do analiz wykorzystano dane pochodzące z pierwszej rundy badania Generacje, Rodziny i Płeć Kulturowa (GGS-PL) przeprowadzonego na przełomie 2010 i 2011 roku. Niniejszy artykuł rozpoczyna się od przeglądu literatury poświęconej potencjalnym determinantom sprawowania opieki nad niesamodzielnymi starszymi rodzicami przez osoby w wieku 45-69 lat. Uwzględniono zobowiązania opiekuńcze tej grupy ludzi wobec starszych rodziców oraz jakość relacji między dorosłymi dziećmi i starszymi rodzicami. W kolejnej części opisano źródło danych oraz metodę analizy. W następnej przedstawione zostały wyniki analiz empirycznych. Artykuł kończy podsumowanie.

\section{PRZEGLĄD LITERATURY, CELE PRACY I PYTANIA BADAWCZE}

Obserwowane od kilkudziesięciu lat zmiany społeczno-demograficzne oznaczają, oprócz zmian struktury wieku ludności, także głębokie przemiany modelu rodziny (por. np. Abramowska-Kmon 2011). Są one uwarunkowane przede wszystkim przeobrażeniami wzorców płodności i umieralności, a także zwiększeniem migracji. Spadek dzietności oznacza, że w rodzinach rodzi się mniej dzieci, przyczyniając się do zmniejszenia liczby osób należących do jednej generacji (tj. rodzeństwa, kuzynów). Natomiast spadek umieralności i w konsekwencji wydłużenie życia sprawia, że współegzystuje coraz więcej osób z kilku generacji. Ten typ więzi rodzinnych jest porównywany do 'tyczki do fasoli' (bean-pole) i oznacza wertykalizację więzi rodzinnych (verticalisation of kinship) (Saraceno 2008, Grundy, Henretta 2006, de Sandre 2006, de Jong Gierveld i Dykstra 2006, 2008, Fokkema, ter Bekke i Dykstra 2008). W przeszłości rodziny złożone z czterech generacji (które najczęściej współegzystowały ze sobą jedynie przez krótki czas) były rzadkością, zaś obecnie przypadki jednoczesnego egzystowania trzech, czterech czy nawet pięciu generacji w rodzinie są relatywnie coraz częstsze i, co warto podkreślić, sytuacje te trwają coraz dłuższej (Golini i Iacoucci 2006, Saraceno 2008, Szukalski 2002, 2008). Warto wspomnieć, że w minionym wieku znacząco zwiększył się czas bycia (dorosłym) dzieckiem (Golini i Iacoucci 2006). W związku z tym nierzadko relacja rodzicedzieci trwa 50-60 lat. Fakt ten ma także istotne znaczenie z punktu widzenia osób określanych w literaturze jako „sandwich generations” (generacje środkowe), które opiekują się zarówno swoimi dziećmi, jak i niesprawnymi starszymi rodzicami (por. np. Myers 1988, Chisholm 1999, Grundy i Henretta 2006, Golini i Iacoucci 2006, Künemund 2006). Należy zwrócić uwagę na to, iż wyniki analiz empirycznych nie zawsze potwierdzają to podwójne obciążenie „sandwich generations”, czyli jed- 
noczesnego sprawowania opieki nad dziećmi i starszymi rodzicami. Na ogół dorośli zajmujący pozycje środkowej generacji są w wieku 30-60 lat. W przypadku młodszych osób z tej grupy (tzn. tych zajmujących się dziećmi), rodzice najczęściej są osobami sprawnymi, a więc samodzielnymi. Natomiast w przypadku osób starszych $\mathrm{z}$ tej grupy wieku (czyli opiekujących się niesprawnymi rodzicami) dzieci już są raczej dorosłe i najczęściej opuściły dom rodzinny. W związku z tym wydaje się, że koncepcja „sandwich generations” jako opiekujących się jednocześnie rodzicami i dziećmi nie zawsze jest właściwym podejściem do wieku dojrzałego (Agree, Bisset i Rendall 2003, Dykstra 1997, Dykstra i Komter 2006). Bardziej odpowiednie jest traktowanie osób dojrzałych jako podwójne obciążonych. Obciążenie to łączy się z wykonywaniem pracy zarobkowej i ze zobowiązaniami opiekuńczymi wobec jednej generacji (wnuków lub starszych rodziców). Warto podkreślić, iż zdecydowana większość osób najprawdopodobniej będzie zaangażowana w sprawowanie opieki nad innymi osobami dorosłymi w pewnym momencie swojego życia (Agree $\mathrm{i}$ in. 2003), ale z różną częstotliwością i rodzajem dostarczanego wsparcia (finansowego, emocjonalnego, opieki osobistej).

Globalizacja oraz ogólnoświatowa dyfuzja nowych technologii komunikacyjnych i informacyjnych sprzyjają nasileniu migracji i międzynarodowej mobilności ludności. W rezultacie $\mathrm{w}$ ostatnich dekadach zaobserwowano w Europie szybki wzrost liczby imigrantów, która osiągnęła najwyższy poziom od drugiej wojny światowej (Attias-Donfut, Wolff 2008). Rosnąca liczba migrantów wpływa nie tylko na struktury demograficzne ludności regionu odpływu i napływu, ale również na wielkość rodzin i gospodarstw domowych oraz ich strukturę w tych regionach. Ponadto wpływając na zmniejszenie się wielkości rodziny i sieci krewniaczych, mogą przyczynić się również do zmian w przepływach międzygeneracyjnych od migrantów do innych członków rodziny (zwłaszcza tej pozostającej w regionie odpływu). Migracje osób młodych i dorosłych przyczyniają się do zmniejszenia liczby potencjalnych opiekunów osób starszych w regionie pochodzenia, którzy z powodu zamieszkiwania w dużej odległości od krewnych, nie są w stanie wypełniać swoich funkcji opiekuńczych (Abramowska-Kmon 2011, Szweda-Lewandowska 2014).

W krajach, gdzie zmiany demograficzne są zaawansowane² coraz częściej opieka nad sędziwymi rodzicami jest sprawowana również przez osoby starsze (tzw. „młodzi starzy"). Dane GGS dla Polski pokazują, że ponad 7\% respondentów w wieku 65-69 lat ma przynajmniej jednego żyjącego rodzica, z czego jedna piąta sprawuje nad nim opiekę. Warto podkreślić, że zajmowanie pozycji środkowej w rodzinie trzylub czterogeneracyjnej stało się naturalnym doświadczeniem osób w wieku późnym dojrzałym i wczesnej starości (de Jong Gierveld i Dykstra 2008, Dykstra i in. 2013).

Mając powyższe rozważania na uwadze, w niniejszej pracy do grupy ,sandwich generations" włączono osoby w wieku 45-69 lata, z tym że uwaga skupiona będzie

2 Symptomami zaawansowanych zmian demograficznych są: niska płodność i umieralność oraz wysoki średni wiek rodzenia, w tym pierwszego, dziecka. 
jedynie na jednej stronie obciążenia opieką tych osób, a mianowicie tylko na zaangażowaniu w opiekę nad starszymi rodzicami. Poniżej przedstawiono przegląd literatury odnośnie do czynników wpływających na sprawowanie opieki nad starszymi rodzicami. W rozważaniach tych uwzględniono zarówno uwarunkowania indywidualne opiekunów determinujące udzielanie pomocy starszym rodzicom (np. płeć, wiek, sytuację rodzinną, poziom wykształcenia), charakterystyki rodziców (np. stan zdrowia), jakość relacji między rodzicami a dorosłymi dziećmi, jak i opinie wobec odpowiedzialności dzieci za opiekę nad rodzicami w potrzebie.

Płeć jest jedną z głównych charakterystyk opiekunów, która znacząco determinuje szanse sprawowania opieki nad starszymi rodzicami. Kobiety, postrzegane jako dostarczycielki różnego rodzaju wsparcia w sieciach społecznych (w rodzinie, wśród znajomych), znacząco częściej opiekują się osobami niesprawnymi (rodzicami/ współmałżonkiem/sąsiadami/innymi krewnymi) niż mężczyźni (por. np. Gerstel i Gallagher 2001, Haberkern i in. 2015, Haberkern i Szydlik 2010, Sherman i in. 1988, Bromley i Blieszner 1997, Bonsang 2007, Jang i in. 2012, Ogg i Renaut 2006, Szweda-Lewandowska 2014). Niemniej jednak warto podkreślić, iż wyniki analiz pochodzące $\mathrm{z}$ różnych krajów nie są spójne: w niektórych krajach kobiety charakteryzują się mniejszym poczuciem obowiązku rodzinnego niż mężczyźni ${ }^{3}$, co z kolei może przekładać się na zachowania, w zaś innych kobiety odczuwają silniejsze zobowiązania wobec rodziny ${ }^{4}$ (por. np. Dykstra i in. 2013). Wyniki analiz przeprowadzonych dla Polski pokazują, że kobiety częściej niż mężczyźni opiekują się osobami starszymi, które potrzebują pomocy (por. np. Pączkowska 2002, Bień 2006, Golinowska 2006, Szczerbińska 2006, Czekanowski 2002, 2006, Grotowska-Leder 2008, Wóycicka 2009, Abramowska-Kmon i Kotowska 2009, Abramowska-Kmon 2011).

Kolejną cechą opiekunów determinującą sprawowania opieki nad starszymi rodzicami jest wiek (Bromley i Blieszner 1997). Można przypuszczać, że wraz z wiekiem dorosłego dziecka wzrasta także wiek żyjącego rodzica, a tym samym prawdopodobieństwo wystąpienia u niego problemów zdrowotnych i niepełnosprawności powodując zwiększenie ryzyka potrzeby pomocy w codziennym życiu.

Wpływ poziomu wykształcenia na sprawowanie opieki nad osobami starszymi jest niejednoznaczny. Na przykład wyniki analiz przeprowadzone przez Bonsang (2007) pokazały, że im wyższy jest poziom wykształcenia dorosłych dzieci, tym większe jest prawdopodobieństwo udzielania pomocy starszym rodzicom. Może to być związane z poczuciem obowiązku wobec starzejących się rodziców. Z jednej strony, osoby lepiej wykształcone mogą charakteryzować się silniejszymi normami poczucia obowiązku, gdyż czują się bardziej zobligowane do pomocy/wspierania rodziców z uwagi na poniesione większe inwestycje w ich wykształcenie niż osoby słabiej wykształcone (por. Dykstra i in. 2013). Z drugiej zaś strony osoby lepiej

\footnotetext{
${ }^{3}$ Na przykład w Norwegii, Holandii, Niemczech i we Francji.

${ }^{4} \mathrm{Na}$ przykład w Rumunii, Bułgarii i Rosji kobiety odznaczały się silniejszymi normami wobec obowiązków rodzinnych niż mężczyźni.
} 
wykształcone charakteryzują się większym poczuciem niezależności i bardziej indywidualistycznym stylem życia, co zmniejsza poczucie obowiązku wobec rodziców i tym samym sprawowanie opieki. Należy także podkreślić, iż koszty alternatywne opieki dla tych osób są większe niż dla osób o niższych kategoriach wykształcenia, co także może przełożyć się na mniejszą skłonność do sprawowania bezpośredniej (osobistej) opieki nad niesamodzielnymi rodzicami. Ponadto lepsza sytuacja finansowa osób z wyższym wykształceniem może zwiększyć możliwości objęcia starszego rodzica odpłatną opieką.

Sprawowanie opieki może mieć duży wpływ na życie codzienne opiekunów, ograniczając ich możliwości zaangażowania się w inne aktywności, włączając pracę zarobkową, zwykłe domowe prace, zobowiązania społeczne, spędzanie wolnego czasu i higienę osobistą (Bittman i in. 2004). Powszechnie uznaje się, że fakt zatrudnienia (pracy zarobkowej) bardzo często konkuruje $\mathrm{z}$ obowiązkami rodzinnymi również $\mathrm{w}$ odniesieniu do starszych rodziców. Jednakże, sprawowanie opieki nieformalnej przez kobiety nie oznacza obecnie ich wycofania się (wyłączenia) z rynku pracy. Coraz częściej jest to tymczasowa rezygnacja z udziału w rynku pracy na pewnych etapach życia, a czasowe wycofanie się z rynku pracy jest coraz częściej wspierane przez regulacje prawne ${ }^{5}$. Warto podkreślić, iż analizy pokazują, że duża część osób sprawujących opiekę łączy ją z pracą zarobkową kosztem innych aktywności, czasu wolnego itp. (Stuifbergen i in. 2008, Leopold i in. 2014).

Stan cywilny i bardziej ogólnie sytuacja rodzinna opiekunów to kolejny czynnik wpływający na sprawowanie opieki nad starszymi rodzicami. Na ogół rozwód i powtórne małżeństwo postrzegane są jako zdarzenia, w wyniku których ulega osłabieniu poczucie obowiązku pomagania innym członkom rodziny (Rossi i Rossi 1990, Dykstra i in. 2013). Z drugiej strony osoby rozwiedzione i te, które nigdy nie zawarły związku małżeńskiego, wykazują silniejsze poczucie odpowiedzialności za bliskich członków rodziny (Wijckmans i van Bavel 2010, Dykstra i Fokkema 2012). Ich większe poczucie obowiązku udzielania wsparcia innym osobom z rodziny wynika prawdopodobnie z tego, jak sami chcieliby być traktowani.

Kolejną cechą wpływającą na świadczenie pomocy starszym rodzicom jest posiadanie rodzeństwa. Brat lub siostra może być alternatywnym lub dodatkowym źródłem wsparcia dla starszych rodziców (Leopold i in. 2014), a posiadanie rodzeństwa może zmniejszyć liczbę kontaktów i pomoc dostarczaną rodzicom przez dorosłe dzieci (Spitze i Logan 1991). Warto podkreślić, iż osoby posiadające jedno dziecko odznaczają się największym prawdopodobieństwem otrzymania pomocy (Haberkern i in. 2015). Jedynacy kontaktują się częściej i pomagają rodzicom więcej niż nie-jedynacy. W szczególności posiadanie siostry znacząco zmniejsza liczbę kon-

${ }^{5}$ Należy również podkreślić, że wycofanie się z rynku pracy (czasowy lub nawet stały brak pracy zarobkowej) związane ze sprawowaniem opieki nad niesamodzielnym członkiem rodziny, ma długotrwałe konsekwencje dla osoby sprawującej opiekę. W szczególności ogranicza (a nawet blokuje) rozwój zawodowy, akumulację środków na własnym koncie emerytalnym, a także zwiększa ryzyko ubóstwa (por. Abramowska-Kmon 2011). 
taktów i wielkość dostarczanego wsparcia starszym rodzicom ${ }^{6}$. Z punktu widzenia opieki nad osobami starszymi struktura płci rodzeństwa wpływa na relacje między rodzicami a dorosłymi dziećmi, kształtując także sposób sprawowania opieki i jej ilość. Uznaje się, że osoby starsze posiadające niewiele dzieci lub niemające córki są w niekorzystniej sytuacji w kontekście otrzymywania nieformalnej opieki i w związku z tym wymagają więcej opieki formalnej. Spitze i Logan (1991) wskazali trzy mechanizmy, które wyjaśniają, w jaki sposób struktura rodzeństwa według płci determinuje relacje starsi rodzice-dorosłe dzieci. Po pierwsze, struktura rodzeństwa według płci może kształtować różne postawy i oczekiwania wobec obowiązku dzieci względem rodziców. Po drugie, dzieci wychowywane w różnych strukturach rodzinnych mogą utworzyć relacje $\mathrm{z}$ ich rodzicami o różnym stopniu bliskości. Po trzecie, potrzeby rodziców i czas przeznaczany na kontakty i wsparcie mogą być widziane różnie w różnych konstelacjach rodzeństwa według płci jako zaspokajane przez źródła alternatywne. Ponadto, mniejsze zaangażowanie w opiekę nad rodzicami nie-jedynaków w porównaniu do jedynaków może być związane z mniejszym poczuciem obowiązku wobec rodziców wykazywanym przez osoby posiadające rodzeństwo, wynikające z rozłożenia opieki na większą liczbę osób (por. np. Dykstra i Fokkema 2012, Dykstra i in. 2013).

Poza charakterystykami indywidualnymi dorosłych dzieci jako opiekunów starszych rodziców znaczącą rolę w sprawowaniu opieki odgrywają także cechy rodziców takie jak: płeć, wiek, stan zdrowia (por. np. Bonsang 2007), jakość relacji rodzice-dzieci oraz opinie na temat odpowiedzialności dorosłych dzieci za opiekę nad niesprawnymi starszymi rodzicami.

Kobiety częściej niż mężczyźni otrzymują różnego rodzaju wsparcia, nie tylko od własnych dzieci (por. np. Attias-Donfut i in. 2005, Ogg i Renaut 2006). Na ogół wraz z wiekiem znacząco pogarsza się stan zdrowia (Abramowska i in. 2005, Abramowska 2005, Abramowska-Kmon 2007, 2008, Abramowska-Kmon i Kotowska 2009, Błędowski 2011, 2012, Doblhammer i in. 2008, Vaupel 2010, Wizner i in. 2012). W szczególności dotyczy to osób sędziwych (tj. w wieku 80 lat lub więcej). W związku z tym, a także zważywszy na odstęp między generacją rodziców i dzieci, można założyć, iż starsi rodzice osób z ,sandwich generations" odznaczają się złym lub bardzo złym stanem zdrowia. Stan zdrowia rodzica jest jedną z kluczowych determinant wpływających na sprawowanie opieki nad nim (Ogg i Renaut 2006, Albuquerque 2014).

Kolejnym, ważnym czynnikiem wpływającym na szansę sprawowania opieki nad starszymi rodzicami jest jakość relacji między nimi a dorosłymi dziećmi (lub inaczej stopień zadowolenia z tej relacji). Brak większych problemów emocjonalnych w relacji starsi rodzice - dorosłe dzieci oznacza, że istnieje między nimi dobra jakościowo więź, która może determinować możliwości i chęci udzielania wsparcia rodzicom w potrzebie (Bromley i Blieszner 1997). Osobiste kontakty między rodzi-

${ }^{6} \mathrm{~W}$ przeliczeniu na jedną osobę udzielającą wsparcia. 
cami i dziećmi tworzone w ciągu całego życia (i jakość relacji) wpływają na chęć opieki nad starszymi rodzicami i rzeczywiście otrzymywane wsparcie (Stuifbergen i in. 2008). Warto także podkreślić, iż jakość relacji między ludźmi ulega ciągłym przeobrażeniom (por. np. van Galen i Dykstra 2006), zwłaszcza w sytuacji wystąpienia znaczących zdarzeń w życiu jednostki (np. urodzenie dziecka, owdowienie, rozwód itp.). Taką sytuacją może być także pojawienie się problemów zdrowotnych i tym samym potrzeby wsparcia starszego rodzica. Zatem jakość relacji między dorosłymi dziećmi a rodzicami może z jednej strony wpływać na szansę sprawowania opieki nad niesamodzielną matką/ojcem, a z drugiej strony może być kształtowana pod wpływem wypełniania tych obowiązków rodzinnych przez dorosłe dzieci.

Kolejną ważną kwestią w udzielaniu pomocy starszym rodzicom jest to, w jaki sposób opinie i postawy na temat odpowiedzialności za opiekę nad osobami starszymi kształtują decyzje i zachowania jednostek. Analizy opinii, wartości i postaw wobec wsparcia międzygeneracyjnego mogą wskazać przesłanki, które stoją za tym zachowaniem (Finch i Mason 1990). Mogą one także być źródłem informacji na temat potencjalnej solidarności rodzinnej (międzygeneracyjnej). Warto zaznaczyć, iż analizy łączące poczucie obowiązku rodzinnego i fakt sprawowania opieki nad starszymi rodzicami dostarczają różnych wyników (por. np. Cooney i Dykstra 2011). $\mathrm{Z}$ jednej strony, osoby, które charakteryzują się większym poczuciem obowiązku wobec rodziców i zdecydowaną opinią na temat odpowiedzialności dzieci za opiekę nad starszymi rodzicami, częściej są zaangażowane w dostarczanie emocjonalnego i instrumentalnego wsparcia rodzicom (Dykstra i in. 2013, Dykstra i Fokkema 2012). $\mathrm{Z}$ drugiej zaś strony, wyniki analiz pokazują brak związku między postawami wobec odpowiedzialności za opiekę nad osobami starszymi a rzeczywistym zaangażowaniem się w opiekę nad niesprawnym rodzicem (Cooney i Dykstra 2011).

Celem niniejszego artykułu jest określenie determinant sprawowania opieki nad starszymi rodzicami przez osoby w wieku 45-69 lat w Polsce. W szczególności chcemy uzyskać odpowiedzi na następujące pytania badawcze:

1. W jaki sposób indywidualne charakterystyki dorosłych dzieci (płeć, wiek, poziom wykształcenia, sytuacja rodzinna, status na rynku pracy, miejsce zamieszkania, posiadanie rodzeństwa, stan zdrowia) wpływają na szansę sprawowania opieki nad starszymi rodzicami?

2. W jaki sposób charakterystyki rodziców (stan zdrowia) i jakość relacji między rodzicami a dorosłymi dziećmi wpływają na prawdopodobieństwo dostarczania wsparcia instrumentalnego starszym rodzicom?

3. Czy (i jeśli tak, to w jaki sposób) opinie na temat odpowiedzialności dorosłych dzieci za opiekę nad starszymi rodzicami wpływają na szanse sprawowania opieki nad matką lub ojcem w potrzebie pomocy?

Innymi słowy chcemy ustalić, czy rezultaty analiz dla Polski są podobne do wyników analiz przeprowadzonych dla innych krajów i opisanymi w niniejszym rozdziale. W szczególności interesująca jest kwestia, czy jakość relacji między dorosłymi dziećmi a starszymi rodzicami determinuje udzielanie wsparcia rodzicom 
w potrzebie. Czy dorosłe dzieci, mimo negatywnej oceny stosunków ze starszymi rodzicami, sprawują nad nimi opiekę? Ponadto, zastanawiające jest to, czy panujące w Polsce dosyć powszechne przekonanie o odpowiedzialności dzieci za niesamodzielnych rodziców, przekłada się na rzeczywiste dostarczanie im wsparcia. Według wiedzy Autorki, tego typu analizy do tej pory nie były prowadzone w Polsce.

\section{DANE I METODA ANALIZY}

\section{DANE I ZMIENNE W ANALIZIE}

Dla przeprowadzenia analiz sprawowania opieki nad starszymi rodzicami przez osoby w wieku 45-69 lat w Polsce wykorzystano dane pochodzące z pierwszej rundy badania Generacje, Rodziny i Płeć Kulturowa (GGS-PL), zrealizowanego na przełomie lat 2010-2011 przez Instytut Statystyki i Demografii SGH we współpracy z Głównym Urzędem Statystycznym ${ }^{7}$. Badanie to przeprowadzono w ramach międzynarodowego programu badań Generations and Gender Programme (GGP) ${ }^{8}$. Jego celem było pozyskanie informacji o procesach demograficznych w Polsce umożliwiających zrozumienie mechanizmów przyczynowo-skutkowych dotyczących tworzenia, rozwoju i rozpadu rodzin, relacji między generacjami, zmian społecznych ról kobiet i mężczyzn (Kotowska i Jóźwiak 2011). W badaniu tym obok biografii rodzinnych, zawodowych, edukacyjnych i migracyjnych respondentów w wieku 18-79 lat zebrano informacje o ich sytuacji materialnej i kontaktach społecznych, a także o normach, wartościach, zamierzeniach i oczekiwaniach osób ankietowanych. Oryginalna baza danych zawierała informacje o blisko 20 tysiącach respondentów w wieku 18-79 lat.

Dla celów niniejszej analizy próba została ograniczona do osób w wieku 45-69 lat, które miały przynajmniej jednego żyjącego rodzica. Ostateczna baza danych zawierała informacje o prawie 3800 osobach. W związku z tym, że oszacowano dwa modele (osobno dla sprawowania opieki nad matką oraz nad ojcem), utworzone zostały dwie binarne zmienne zależne, gdzie 1 - oznaczało sprawowanie opieki, 0 - brak sprawowania opieki nad rodzicem danej płci. Utworzona zmienna bazowała na informacjach uzyskanych na podstawie następujących pytań:

1. „Czy w ciągu ostatnich 12 miesięcy udzielał(a) Pan(i) regularnej pomocy innym osobom dorosłym w czynnościach codziennych, takich, jak jedzenie, wstawanie, ubieranie się, kąpiel, czy korzystanie z toalety?" z odpowiedziami 1 - tak, $2-$ nie. $^{9}$

\footnotetext{
7 Projekt badawczy realizowany ze środków Ministerstwa Nauki i Szkolnictwa Wyższego, nr projektu 554/N-UNECE/2009/0. Więcej informacji na stronie: http://kolegia.sgh.waw.pl/pl/KAE/struktura/ ISiD/projekty/ggs-pl/Strony/default.aspx.

8 Więcej na stronie: www.ggp-i.org.

9 Mankamentem tego pytania jest brak informacji o częstotliwości udzielanej opieki.
} 
2. „Komu Pan(i) pomagał(a)?” z 19 kategoriami odpowiedzi (m.in. matka, ojciec) i możliwością wyboru do 5 osób, dzięki czemu możliwe było uzyskanie informacji, o sprawowanej opiece nad rodzicami.

Zmiennymi niezależnymi w modelu były podstawowe zmienne społeczno-demograficzne dorosłych dzieci (płeć, wiek, miejsce zamieszkania, stan zdrowia mierzony występowaniem ograniczeń przy wykonywaniu podstawowych czynności życiowych) oraz zmienne opisujące sytuację rodzinną (typ gospodarstwa domowego: mieszkający samotnie, tylko ze współmałżonkiem, ze współmałżonkiem i innymi osobami, bez współmałżonka z innymi osobami), aktywność zawodową, poziom wykształcenia oraz posiadanie rodzeństwa. Ponadto, z uwagi na cel niniejszej pracy, do modeli włączono zmienne opisujące opinię o odpowiedzialności za opiekę nad rodzicami w potrzebie ${ }^{10}$, zadowolenie $\mathrm{z}$ relacji z danym rodzicem, a także stan zdrowia rodzica (mierzony występowaniem ograniczonej zdolności wykonywania podstawowych czynności).

Tablica 1 przedstawia statystyki opisowe zmiennych objaśniających w modelu. Średni wiek respondentów w wieku 45-69 lat wyniósł 53,6 lat. Ponad 57\% ostatecznej próby stanowiły kobiety. Natomiast $64 \%$ analizowanej grupy mieszkało w mieście. Zdecydowaną większość (ponad 70\%) stanowiły osoby legitymujące się wykształceniem średnim. Mniej niż połowa (45\%) mieszkała ze współmałżonkiem/partnerem i innymi osobami w jednym gospodarstwie domowym. Ponad $90 \%$ respondentów nie odczuwało ograniczeń przy wykonywaniu podstawowych czynności życiowych, zaś ponad połowa z nich posiadała zatrudnienie. Rzadziej niż co 10 respondent $\mathrm{w}$ tej próbie był jedynakiem. Zdecydowana większość ankietowanych zgadzała się z opinią, że dzieci powinny być odpowiedzialne za opieką nad rodzicami, gdy są oni w potrzebie. Jakość relacji z rodzicem została wyrażona poprzez satysfakcję ze stosunków z rodzicem. Zmienna ta była mierzona w skali od 0 (zupełnie niezadowolony) do 10 (całkowicie zadowolony). Zadowolenie $\mathrm{z}$ relacji z rodzicami było wysokie, nieco większe dla relacji z matką niż z ojcem (średnie wyniosły odpowiednio 8,5 i 8,4). Matka niemal co czwartego respondenta odczuwała problemy zdrowotne (niepełnosprawność), sytuacja ta dotyczyła 18\% ojców. Prawie wszystkie zmienne niezależne (z wyjątkiem wieku, satysfakcji z relacji z rodzicem i opinii o odpowiedzialności za opiekę nad rodzicami w potrzebie) włączono do modelu jako zmienne jakościowe przekodowane odpowiednio na zmienne binarne. W przypadku zmiennych przyjmujących więcej niż dwie kategorie zastosowano standardową procedurę wyodrębnienia kategorii odniesienia polegającą na utworzeniu zestawu zmiennych zero-jedynkowych dla każdej wartości zmiennej. Następnie

10 Na podstawie pytania: W jakim stopniu zgadza się Pan(i) z następującymi stwierdzeniami? „Dzieci powinny być odpowiedzialne za opiekę nad rodzicami, gdy są oni w potrzebie." Z odpowiedziami na skali Likerta: od 1 - zdecydowanie zgadzam się do 5 - zdecydowanie nie zgadzam się. Na potrzeby niniejszej analizy odpowiedzi te zostały odpowiednio przekodowane, tzn. 1 oznaczało: zdecydowanie nie zgadzam się, a 5 - zdecydowanie zgadzam się. 


\begin{tabular}{|c|c|c|c|c|c|c|c|c|c|c|c|c|}
\hline \multirow{2}{*}{ 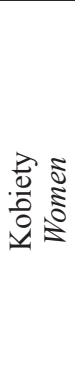 } & 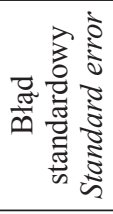 & $\begin{array}{l}0 \\
n \\
n\end{array}$ & $\stackrel{\infty}{\rightarrow}$ & $\begin{array}{r}\hat{i} \\
\hat{i}\end{array}$ & $\begin{array}{l}n \\
b \\
0\end{array}$ & 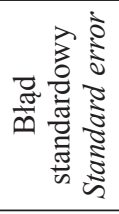 & & $\vec{\Xi}$ & $\vec{\Xi}$ & & $\begin{array}{l}0 \\
0 \\
0 \\
0\end{array}$ & $\begin{array}{l}0 \\
0 \\
0\end{array}$ \\
\hline & 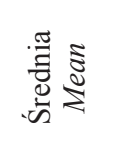 & $\stackrel{+}{n}$ & $\begin{array}{l}\hat{b} \\
\infty\end{array}$ & $\underset{\infty}{\stackrel{f}{+}}$ & बे & 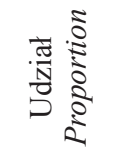 & & $\vec{Z}$ & $\bar{Z}$ & & $\begin{array}{l}0 \\
\text { m. } \\
\text { ?. }\end{array}$ & $\begin{array}{l}\text { J্ } \\
\text { : } \\
0\end{array}$ \\
\hline \multirow{2}{*}{ 交 } & 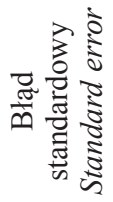 & $\begin{array}{l}\dot{f} \\
i n\end{array}$ & $\begin{array}{l}n \\
i \\
i\end{array}$ & $\frac{ \pm}{a}$ & $\begin{array}{l}\mathbb{J} \\
0\end{array}$ & 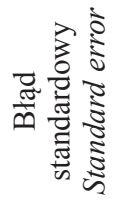 & & $\vec{Z}$ & $\vec{Z}$ & & $\frac{1}{0}$ & $\frac{1}{0}$ \\
\hline & 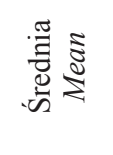 & $\begin{array}{l}\hat{n} \\
\text { nn }\end{array}$ & $\begin{array}{l}\vec{m} \\
\infty\end{array}$ & $\begin{array}{l}\infty \\
\text { ஸ } \\
\infty\end{array}$ & ले & 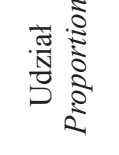 & & $\vec{\Xi}$ & $\vec{\Xi}$ & & సે & $\begin{array}{l}\infty \\
0 \\
0 \\
0 \\
0\end{array}$ \\
\hline \multirow{2}{*}{ 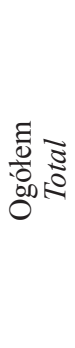 } & 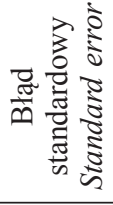 & $\begin{array}{l}n \\
n \\
n\end{array}$ & $\hat{\sigma}$ & $\frac{a}{i}$ & $\begin{array}{l}\tilde{6} \\
0 \\
0\end{array}$ & 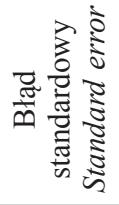 & & $\begin{array}{l}\infty \\
8 \\
0 \\
0\end{array}$ & $\begin{array}{l}\infty \\
8 \\
0\end{array}$ & & $\begin{array}{l}\infty \\
8 \\
0 \\
0\end{array}$ & $\begin{array}{l}\infty \\
8 \\
0 \\
0\end{array}$ \\
\hline & 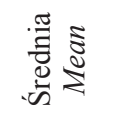 & $\begin{array}{l}\vec{\delta} \\
\tilde{n}\end{array}$ & $\begin{array}{l}\dot{n} \\
\infty \\
\infty\end{array}$ & $\begin{array}{l}0 \\
\overbrace{\infty}\end{array}$ & $\begin{array}{l}\stackrel{\infty}{\curvearrowright} \\
\text { r. }\end{array}$ & 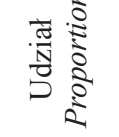 & & $\begin{array}{l}\stackrel{\infty}{\Im} \\
\stackrel{\sigma}{\sigma}\end{array}$ & $\frac{N}{n}$ & & $\begin{array}{l}\text { 尺े } \\
\text { ñ. } \\
0\end{array}$ & $\begin{array}{l}\text { \& } \\
\text { O. } \\
0\end{array}$ \\
\hline & 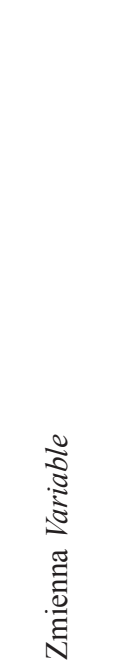 & $\begin{array}{l}0 \\
\square \\
\frac{0}{0} \\
3\end{array}$ & 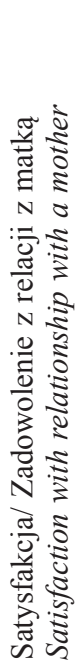 & 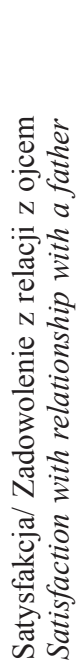 & 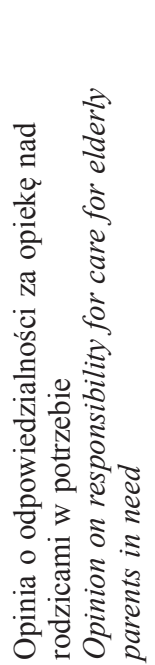 & 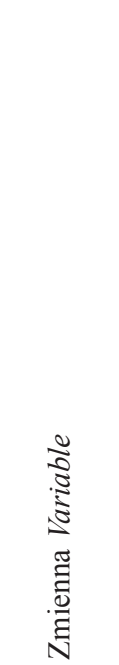 & $\begin{array}{l}\tilde{J} \\
\tilde{u} \\
\tilde{u} \\
\tilde{\omega}\end{array}$ & 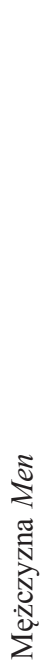 & 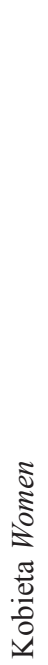 & 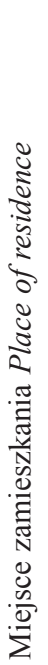 & 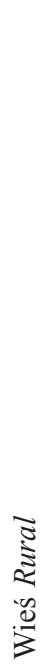 & 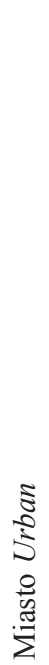 \\
\hline
\end{tabular}


Determinanty sprawowania opieki nad starszymi rodzicami w Polsce...

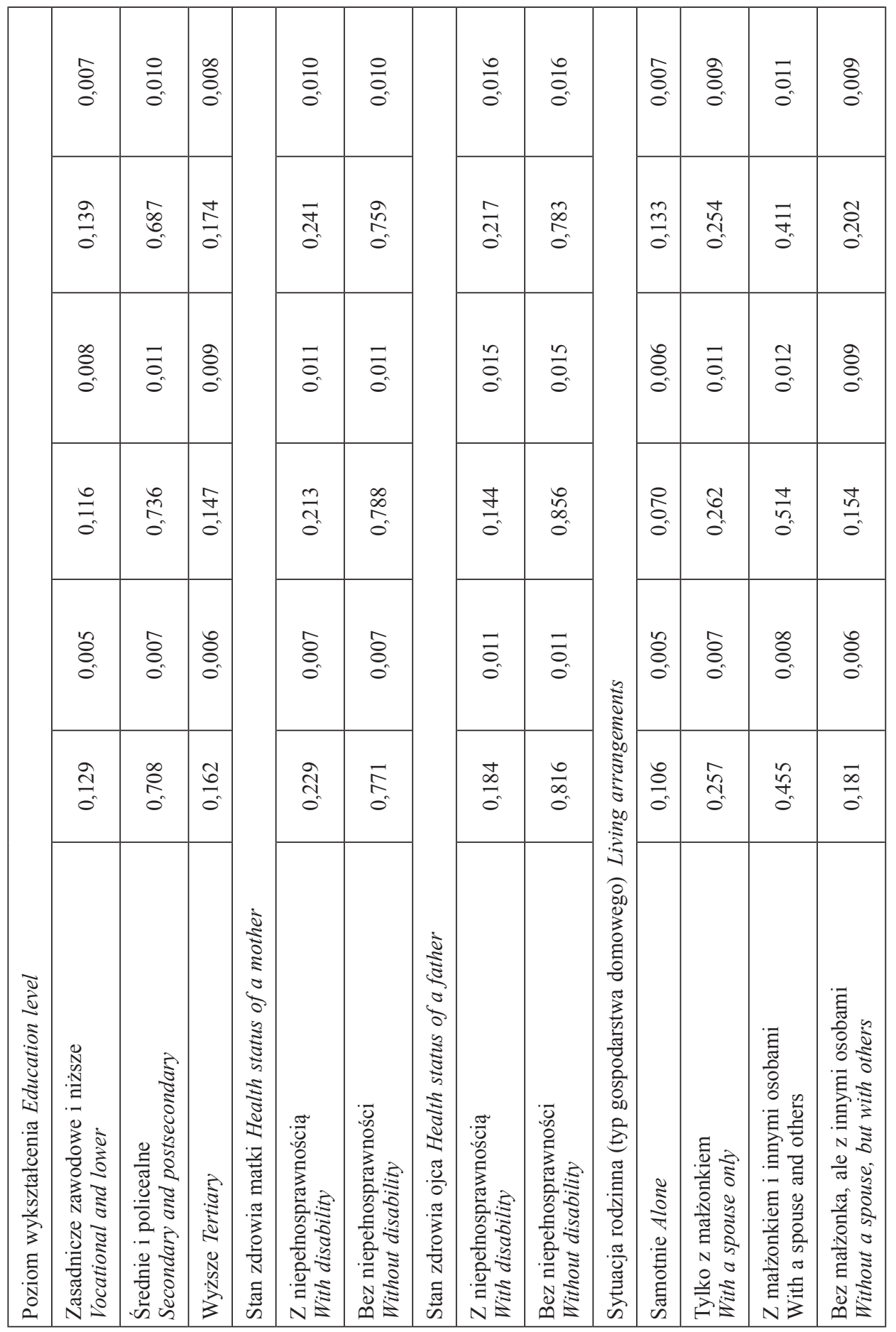




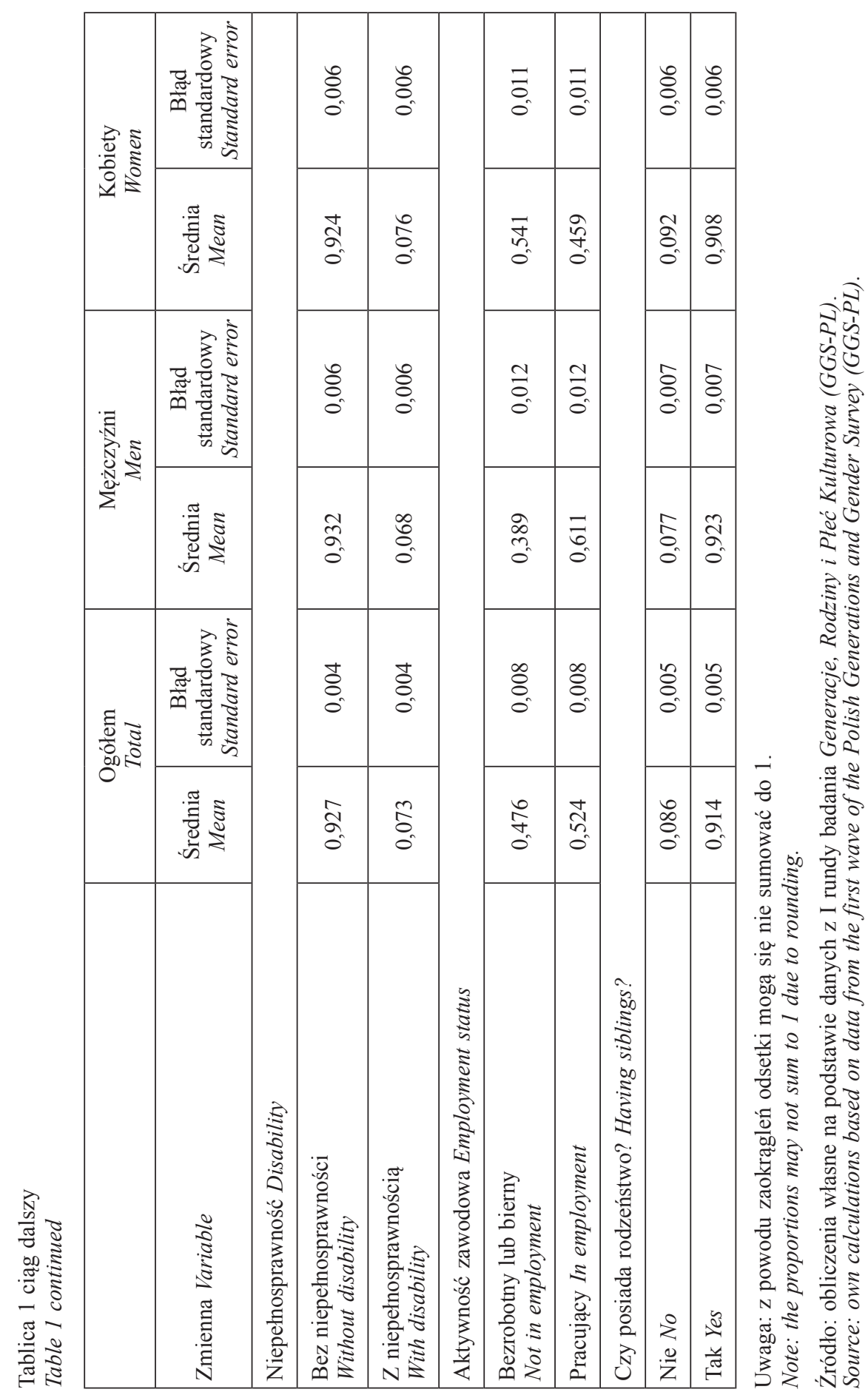


do modelu włączono wszystkie nowopowstałe zmienne binarne oprócz jednej - tej, która miała być właśnie kategorią referencyjną (odniesienia). W kolejnej podsekcji przedstawiono, jakie kategorie zmiennych niezależnych w modelu były kategoriami odniesienia.

\section{METODA}

Do określenia czynników, które wpływają na sprawowanie opieki nad starszymi rodzicami przez respondentów w wieku 45-69 lat, zastosowano model regresji logistycznej dla zmiennej binarnej, który może być zapisany następująco (Wooldridge 2006):

$$
P\left(y_{i}=1\right)=\frac{\exp \left(\beta_{0}+\boldsymbol{x} \boldsymbol{\beta}\right)}{1+\exp \left(\beta_{0}+\boldsymbol{x} \boldsymbol{\beta}\right)}
$$

gdzie:

$\boldsymbol{x} \boldsymbol{\beta}$ - wektor niezależnych zmiennych losowych $(\boldsymbol{x})$ wraz z odpowiadającymi im współczynnikami regresji logistycznej $(\boldsymbol{\beta})$ :

$$
\boldsymbol{x} \boldsymbol{\beta}=\beta_{1} x_{1}+\beta_{2} x_{2}+\ldots+\beta_{k} x_{k}
$$

$\beta_{0}-$ stała w modelu.

W przypadku jakościowych zmiennych niezależnych kategorie odniesienia (referencyjne) były następujące: płeć (ref. mężczyzna), poziom wykształcenia (ref. zasadnicze zawodowe i niższe), sytuacja rodzinna (ref. mieszkający samotnie), status na rynku pracy (niepracujący), stan zdrowia respondenta (ref. bez niepełnosprawności), miejsce zamieszkania (ref. wieś), stan zdrowia rodzica (ref. bez niepełnosprawności), posiadanie rodzeństwa (ref. brak rodzeństwa).

\section{WYNIKI}

$\mathrm{Na}$ wykresie 1 przedstawiono informacje obrazujące zaangażowanie osób w wieku 45-69 lat w opiekę przynajmniej nad jednym żyjącym rodzicem. Zaangażowanie w opiekę wyrażone zostało jako udział osób, które sprawowały opiekę nad starszymi rodzicami, wśród osób danej kategorii posiadających przynajmniej jednego żyjącego rodzica. Dane z badania GGS-PL pokazują, iż co dziesiąty respondent w wieku 45-69 lat był opiekunem starszego rodzica. Generalnie wraz z wiekiem dorosłego dziecka rośnie udział osób opiekujących się regularnie starszymi rodzicami, czego można było oczekiwać, ze względu na większe problemy zdrowotne doświadczane przez sędziwych rodziców. 
Wykres 1. Udział osób w wieku 45-69 lat sprawujących opiekę przynajmniej nad jednym rodzicem według wieku dorosłego dziecka

Figure 1. Proportion of persons aged 45-69 years providing care to at least one parent by age of an adult child

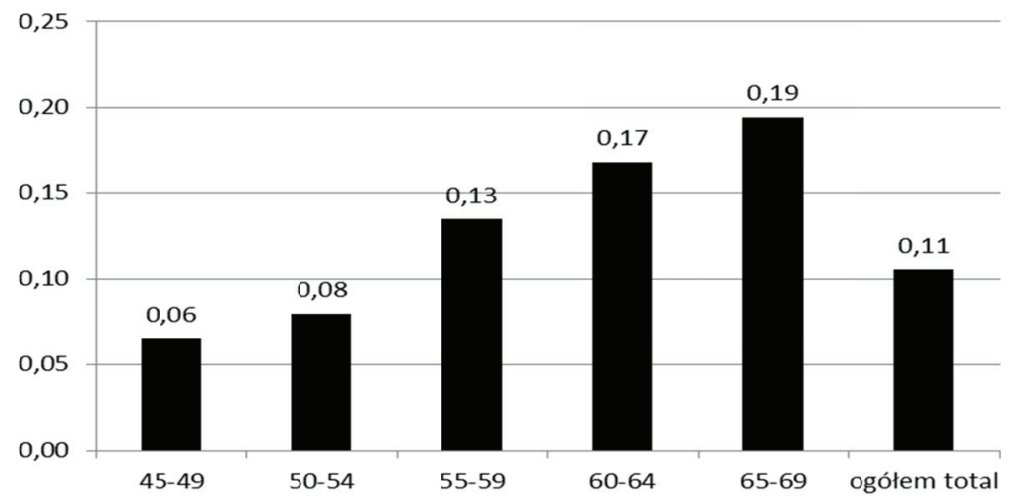

Uwaga: Wielkości dla grupy wieku 65-69 lat należy traktować z ostrożnością z uwagi na małą liczebność.

Note: Results for the age group 65-69 should be treated with caution due to small numbers.

Źródło: obliczenia własne na podstawie danych z I rundy badania Generacje, Rodziny i Płeć Kulturowa (GGS-PL).

Source: own calculations based on data from the first wave of the Polish Generations and Gender Survey (GGS-PL).

W tablicy 2 podano oszacowania wartości parametrów obu modeli przy poszczególnych zmiennych niezależnych w postaci tzw. ilorazów szans (odds ratio), czyli stosunku szans zajścia danego zdarzenia w porównaniu do szans zajścia tego zdarzenia dla wybranych grup referencyjnych. Generalnie uzyskane rezultaty pokazują, że wpływ większości zmiennych objaśniających jest zgodny z ustaleniami pochodzącymi z innych analiz opisanych w literaturze dotyczącej sprawowania opieki nad starszymi rodzicami przez dorosłe dzieci.

Wyniki niniejszych analiz pokazały, że wpływ miejsca zamieszkania, sytuacji rodzinnej, statusu na rynku pracy i stanu zdrowia respondenta na szansę sprawowania opieki nad starszym rodzicem są nieistotne statystycznie dla obu modeli. Ponadto w Modelu 2 nieistotny statystycznie okazał się wpływ posiadania rodzeństwa oraz satysfakcja z relacji z ojcem (rodzicem). W pozostałych przypadkach oszacowania parametrów są statystycznie istotne na poziomie istotności 0,05 oraz w niektórych przypadkach na poziomie 0,1 .

Jak można było oczekiwać, kobiety odznaczają się większym prawdopodobieństwem sprawowania opieki nad rodzicami niż mężczyźni. W przypadku opieki nad matką (model 1) szanse te były niemalże 3-krotnie, zaś w modelu 2 (opieka nad ojcem) ponad 5-krotnie wyższe niż dla mężczyzn. Wraz z wiekiem dorosłego dziecka rośnie prawdopodobieństwo sprawowania opieki nad ojcem lub matką, co wydaje się zrozumiałe, gdyż im starsze dziecko, tym starszy rodzic i tym większe 
Determinanty sprawowania opieki nad starszymi rodzicami w Polsce...

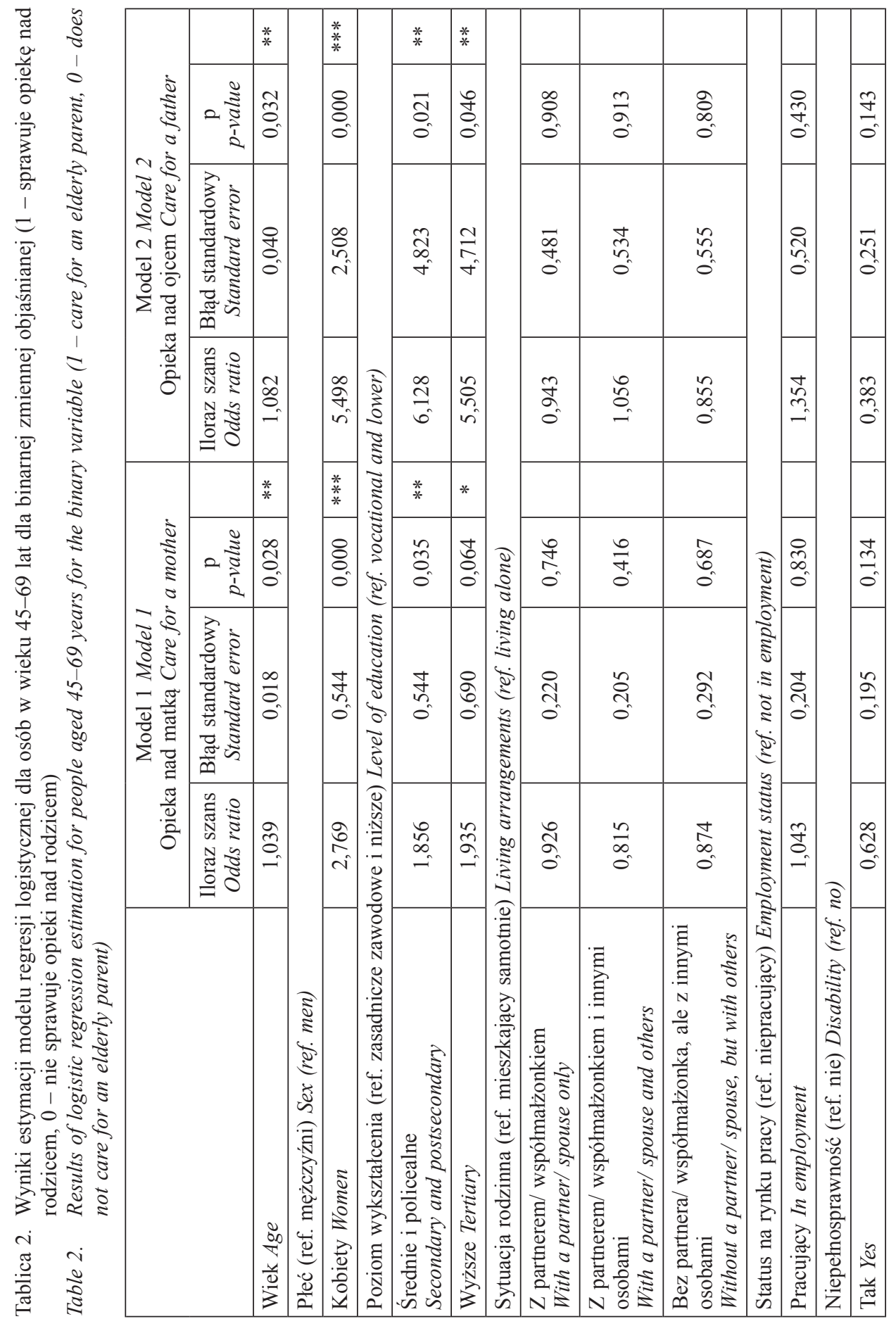




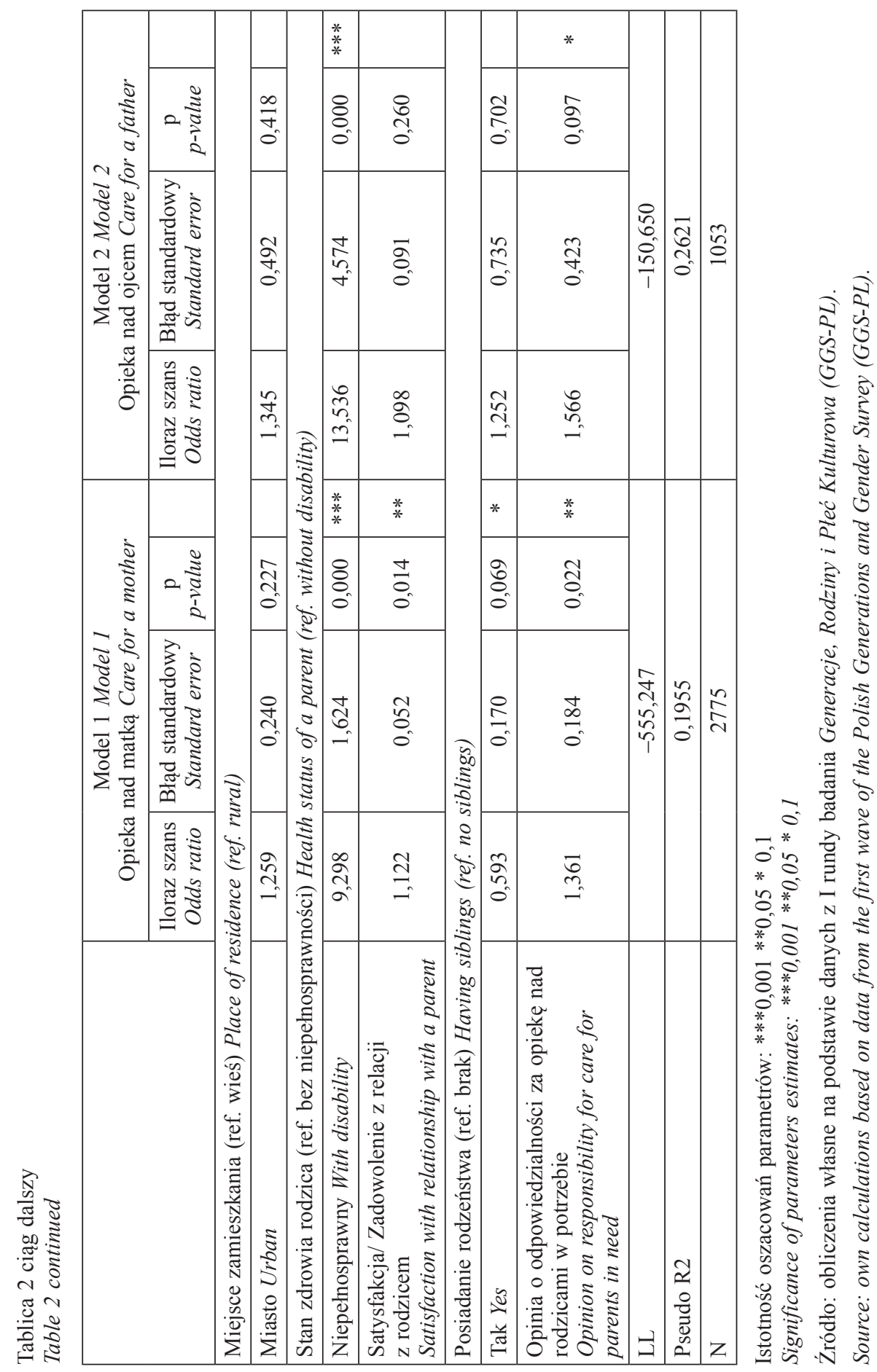


jego problemy zdrowotne i potrzeba wsparcia przy wykonywaniu podstawowych czynności życiowych. Osoby o wyższych kategoriach wykształcenia (średnie i policealne oraz wyższe) charakteryzowały się istotnie większą szansą opiekowania się starszymi rodzicami: w modelu 1 były one blisko dwukrotnie wyższe, a w modelu 2 nawet 5,5-6 krotnie wyższe niż dla osób z wykształceniem co najwyżej zasadniczym zawodowym. Zły stan zdrowia rodzica w znaczący sposób zwiększa prawdopodobieństwo matką lub ojcem: są one odpowiednio ponad 9-krotnie i ponad 13-krotnie wyższe niż w przypadku braku niepełnosprawności. Podobnie im bardziej dorosłe dziecko zgadzało się z opinią, że dzieci powinny być odpowiedzialne za opiekę nad rodzicami, gdy są oni w potrzebie, tym większa była szansa sprawowania opieki nad rodzicem. Podobnie, im większa satysfakcja z relacji z matką, tym większe prawdopodobieństwo udzielania jej pomocy, z kolei w przypadku ojca wpływ jakości relacji na szansę sprawowania opieki okazał się nieistotny statystycznie. Posiadanie rodzeństwa znacząco zmniejszało szanse sprawowania opieki nad matką: osoby posiadające brata lub siostrę charakteryzowały się o 40\% mniejszym prawdopodobieństwem sprawowania opieki, zaś w przypadku ojca obecność rodzeństwa okazała się nieistotne statystycznie.

\section{PODSUMOWANIE}

Celem artykułu było wskazanie determinant sprawowania opieki nad starszymi rodzicami przez dorosłe dzieci. Wyniki analiz są w większości zgodne z wynikami uzyskanymi przez innych badaczy i opisanymi w literaturze przedmiotu. Generalnie wraz z wiekiem rośnie prawdopodobieństwo sprawowania opieki nad ojcem lub matką. Kobiety odznaczają się większym ryzykiem sprawowania opieki nad rodzicami niż mężczyźni. Osoby lepiej wykształcone (średnie i policealne oraz wyższe) charakteryzowały się większym prawdopodobieństwem opiekowania się starszymi rodzicami. Miejsce zamieszkania (miasto - wieś), sytuacja rodzinna, status na rynku pracy i stan zdrowia respondenta nie wpływały istotnie na szansę sprawowania opieki nad starszym rodzicem. W Modelu 1 (sprawowanie opieki nad matką) istotny statystycznie okazał się wpływ posiadania rodzeństwa oraz satysfakcja z relacji z rodzicem. Jak można było przypuszczać, stan zdrowia rodzica w znaczący sposób zwiększa prawdopodobieństwo sprawowania opieki nad matką lub ojcem. Podobnie, im bardziej dorosłe dzieci zgadzały się z opinią na temat odpowiedzialności dzieci za opiekę nad rodzicami, tym większe było ryzyko udzielania im pomocy. Także im lepsze były relacje między rodzicami i dorosłymi dziećmi, tym większe były szanse sprawowania opieki nad ojcem lub matką.

Warto podkreślić, iż w badaniu GGS-PL zebrano informacje o regularnej pomocy innym osobom przy wykonywaniu podstawowych czynności życiowych. Brakuje niestety danych, jaka jest to pomoc i jaka jest jej częstotliwość (raz w tygodniu, kilka razy w tygodniu czy kilka razy dziennie), ani jak długo trwa. Te szczegółowe 
informacje dotyczące sprawowania opieki mogłyby być przydatne w ocenie jej determinant. Poza tym wyniki te zostały uzyskane na podstawie danych przekrojowych, a wydaje się, że bardziej odpowiednie do tego celu byłyby dane panelowe, dzięki czemu możliwe byłoby wychwycenie momentu rozpoczęcia sprawowania opieki, bowiem - jak podają Schulz i Sherwood (2008) - na przykład wzrost poziomu stresu i depresji najbardziej widoczny jest w momencie podjęcia takiego zobowiązania. Dzięki temu można byłoby również zauważyć zmianę (jeśli taka miałaby miejsce) w ocenie jakości relacji między rodzicami a dorosłymi dziećmi w momencie zaangażowania się w opiekę nad rodzicem. Można przypuszczać, iż wykorzystanie tego typu danych pozwoliłoby na poszerzenie zakresu analiz i dostarczyłoby nowych, interesujących wniosków na temat sprawowania opieki nad niesamodzielnymi rodzicami. Zatem, można oczekiwać, że realizowana na przełomie lat 2014 i 2015 kolejna runda badania GGS w Polsce uzupełni tę lukę.

Podsumowując, należy stwierdzić, iż sprawowanie opieki nad niesamodzielnym krewnym, a w szczególności rodzicem jest zajęciem trudnym zarówno pod względem fizycznym, jak i emocjonalnym. Prowadzi to do zwiększenia poziomu stresu, spadku dochodów (związanych z czasowym lub stałym zaniechaniem lub ograniczenia zatrudnienia) i może przyczyniać się do pogorszenia jakości życia/ zadowolenia z życia i tym samym do powstania lub nasilenia się złych relacji między dorosłymi dziećmi a starszymi rodzicami. Z drugiej strony, może być postrzegane jako pozytywne doświadczenie, zwłaszcza w przypadku dobrych relacji między dorosłymi dziećmi i starszymi rodzicami. Kwestia dostarczania pomocy starszym rodzicom (i szerzej innym członkom rodziny i znajomym) jest niezwykle ważna $z$ punktu widzenia starzenia się ludności w Polsce i zmniejszania się tzw. potencjału opiekuńczego w społeczeństwie (Szweda-Lewandowska 2014). Stopień niedopasowania zapotrzebowania na opiekę i potencjalnych zasobów opieki może w przybliżeniu pokazywać popyt na formalne usługi opiekuńcze (zarówno dostarczane przez instytucje publiczne jak i nabywane na rynku usług). A to z kolei znacząco zwiększa koszty związane z populacją osób starszych i starzeniem się ludności. W związku z tym warto prowadzić dalsze analizy w tym zakresie.

\section{LITERATURA}

Abramowska A., 2005, Projekcja liczby osób starszych wymagających opieki w Polsce, raport z badań własnych, ISiD, KAE, SGH.

Abramowska A., Gourbin C., Wunsch G., 2005, Projections of the dependent elderly population by age, sex, and household composition: Scenarios for Belgium, „Archives of Public Health”, nr 63(5): $243-257$.

Abramowska-Kmon A., 2007, Indywidualne demograficzno-spoteczne determinanty stanu zdrowia osób starszych - próba kwantyfikacji ich wpływu, raport z badań własnych, ISiD KAE, SGH.

Abramowska-Kmon A., 2008, Indywidualne demograficzno - spoleczne determinanty stanu zdrowia osób starszych - próba kwantyfikacji ich wptywu, [w:] Kowaleski J.T., Szukalski P. (red.), Pomyślne 
starzenie się w świetle nauk o zdrowiu (s. 206-218), Zakład Demografii i Gerontologii Społecznej UŁ, Łódź.

Abramowska-Kmon A., 2011, Zmiany modelu rodziny a zapotrzebowanie na ustugi opiekuńcze dla osób starszych, maszynopis pracy doktorskiej, Instytut Statystyki i Demografii, Kolegium Analiz Ekonomicznych, Szkoła Główna Handlowa w Warszawie, Warszawa.

Abramowska-Kmon A., Kotowska I.E., 2009, Ustugi opiekuńcze dla osób starszych, [w:] Kotowska I.E. (red.), Rynek pracy $i$ wykluczenie społeczne w kontekście percepcji Polaków - Diagnoza Społeczna 2009 (s. 73-88), Raport tematyczny dla Ministerstwa Pracy i Polityki Społecznej, Warszawa.

Agree E., Bisset, B., Rendall, M.S., 2003, Simultaneous care for parents and care for children among mid-life British women, „Population Trends”, nr 112, 29-35.

Albuquerque P.C., 2014, Intergenerational private transfers: Portugal in the European context, „European Journal of Ageing”, nr 11(4), 301-312.

Attias-Donfut C., Ogg J., Wolff F.-C., 2005, European patterns of intergenerational financial and time transfers, „European Journal of Ageing”, nr 2(3), 161-173.

Attias-Donfut C., Wolff F.-Ch., 2008, Patterns of intergenerational transfers among immigrants in France: a comparative perspective, [w:] Ch. Saraceno (red.), Families, Ageing and Social Policy: Intergenerational Solidarity in European Welfare States (s. 259-284), Edward Elgar Publishing, Cheltenham, UK.

Bień B. (red.), 2006, Family caregiving for the elderly in Poland, Wydawnictwo Uniwersyteckie Transhumana, Białystok.

Bittman M., Fast J.E., Fisher K., Thomson C., 2004, Making the invisible visible: the life and time(s) of informal caregivers, [w:] N. Folbore, M. Bittman (red.), Family time: the social organization of care (s. 69-90), Routledge, London and New York.

Błędowski P., 2011, Sytuacja ekonomiczna i potrzeby opiekuńcze osób starszych w Polsce, „Polityka Społeczna”, nr specjalny „Aspekty medyczne, psychologiczne, socjologiczne i ekonomiczne starzenia się ludzi w Polsce. PolSenior", 31-36.

Błędowski P., 2012, Potrzeby opiekuńcze osób starszych, [w:] M. Mossakowska, A. Więcek, P. Błędowski (red.), Aspekty medyczne, psychologiczne, socjologiczne i ekonomiczne starzenia się ludzi w Polsce (s. 449-466), Termedia Wydawnictwo Medyczne, Poznań.

Bonsang E., 2007, How do middle-aged children allocate time and money transfers to their older parents in Europe?, „Empirica”, nr 34(2), 171-188.

Bromley M.C., Blieszner R., 1997, Planning for Long-Term Care: Filial Behavior and Relationship Quality of Adult Children with Independent Parents, „Family Relations”, vol. 46, nr 2, 155-162.

Chisholm J.F., 1999, The Sandwich Generation, „Journal of Social Distress and the Homeless”, vol. 8, nr 3, 177-191(15).

Cooney T.M., Dykstra P.A., 2011, Family obligations and support behaviour: a United States-Netherlands comparison, „Ageing \& Society”, nr 31, 1026-1050.

Czekanowski P., 2002, Rodzina w życiu osób starszych i osoby starsze w rodzinie, [w]: B. Synak (red.), Polska Starość (s. 140-172), Wydawnictwo Uniwersytetu Gdańskiego.

Czekanowski P., 2006, Family carers of elderly people, [w:] Bień B. (red.), Family caregiving for the elderly in Poland (s. 85-111), Wydawnictwo Uniwersyteckie Transhumana, Białystok.

De Jong Gierveld J., Dykstra P.A., 2006, Impact of longer life on care giving from children, [w:] Yi Z., Crimmins E.M., Carrière Y., Robine J.-M. (red.), Longer life and healthy aging (s. 239-259), Springer, Dordrecht.

De Jong Gierveld J., Dykstra P.A., 2008, Virtue is its own reward? Support-giving in the family and loneliness in middle and old age, „Ageing and Society”, nr 28, 271-287.

De Jong-Gierveld J., van Solinge H., 1995, Ageing and its consequences for the socio-medical system, Population Studies 29, Council of Europe Press, Strasbourg.

De Sandre P., 2006, From the Life Cycle to Life Paths and to Life Transitions, [w:] G. Casselli, J. Vallin, G. Wunsch (red.), Demography: analysis and synthesis: a treatise in population studies (s. 399-417), Elsevier. 
Doblhammer G., Zieger U., Martikainen P., Nihtilä E., Apt W., 2008, Health and its effect on the future demand for care, [w:] Gaymu J., Festy P., Poulain M., Beets G., Future Elderly Living Conditions in Europe (s. 141-163), Les Cahiers de l'Ined, INED.

Doblhammer G., Ziegler U., 2006, Future elderly living conditions in Europe: demographic insights, [w:] Backes G.M., Lasch V., Reimann K. (red.), Gender, health and ageing: European perspectives on life course, health issues and social challenges (s. 267-292), VS Verlag, Wiesbaden.

Dykstra P.A., 1997, Employment and caring, NIDI Working Paper 1997/7. The Hague: Netherlands Interdisciplinary Demographic Institute.

Dykstra P. A., Komter, A.E., 2006, Structural characteristics of Dutch kin networks, [w:] P.A. Dykstra, M. Kalmijn, T.C.M. Knijn, A.E. Komter, A.C. Liefbroer \& C.H. Mulder (Eds.), Family solidarity in the Netherlands (s. 21-42). Amsterdam: Dutch University Press.

Dykstra P. A., Fokkema T., 2012, Norms of filial obligation in the Netherlands, „Population-E”, nr 67(1), $97-122$.

Dykstra P., van den Broek T., Muresan C., Haragus M., Haragus P.-T., Abramowska-Kmon A., Kotowska I.E., 2013, State-of-the-art report Intergenerational linkages in families, Families and Societies Working Paper Series 1(2013).

Finch J., Mason J., 1990, Filial obligations and kin support for elderly people, „Ageing \& Society”, nr $10,151-175$.

Fokkema T., ter Bekke S., Dykstra P.A., 2008, Solidarity between Barents and their adult children in Europe, NIDI Report No. 76.

Folbore N., Bittman M., 2004, Family time: the social organization of care, Routledge, London and New York.

Gerstel N., Gallagher S. K., 2001, Men 's caregiving: Gender and the contingent nature of care, „Gender \& Society", nr 15(2), 197-217.

Golini A., Iacoucci R., 2006, Demographic trends and relationships between generations, [w:] G. Casselli, J. Vallin, G. Wunsch (red.), Demography: analysis and synthesis: a treatise in population studies (s. 305-325), Elsevier.

Golinowska S., 2006, Przedmowa, [w:] Szczerbińska K., (red.), Dostęność opieki zdrowotnej i pomocy społecznej dla osób starszych w Polsce (s. 13-17), Wydawnictwo Uniwersytetu Jagiellońskiego, Kraków.

Grotowska-Leder J., 2008, Sieci społeczne seniorów mieszkajacych $w$ rejonach niezurbanizowanych w perspektywie teoretycznej i empirycznej, [w:] Kowaleski J.T, Szukalski P. (red.), Pomyślne starzenie się w perspektywie nauk o pracy i polityce społecznej (s. 171-185), Zakład Demografii i Gerontologii Społecznej UŁ, Łódź.

Grundy E., Henretta J.C., 2006, Between elderly parents and adult children: a new look at the intergenerational care provided by the 'sandwich generation', ,Ageing \& Society”, nr 26.

Haberkern K., Schmid T., Szydlik M., 2015, Gender differences in intergenerational care in European welfare states, „Ageing and Society”, nr 35(2), 298-320.

Haberkern K., Szydlik M., 2010, State care provision, societal opinion and children's care of older parents in 11 European countries, „Ageing \& Society”, nr 30(2), 299-323.

Jang S.-N., Avendano M., Kawachi I., 2012, Informal Caregiving Patterns in Korea and European Countries: A Cross-National Comparison, „Asian Nursing Research”, nr 6(1), 19-26.

Kotowska I.E., Jóźwiak J., 2011, Panelowe badanie przemian relacji między pokoleniami, w rodzinie oraz między kobietami i mężczyznami: generacje, rodziny i pteć kulturowa - GGS-PL, „Studia Demograficzne", nr 1/159, 99-106.

Künemund H., 2006, Changing Welfare States and the "Sandwich Generation": Increasing Burden for the Next Generation?, „International Journal of Ageing and Later Life”, nr 1(2), 11-29.

Leopold T, Raab M., Engelhardt H., 2014, The Transition to Parent Care: Costs, Commitments, and Caregiver Selection Among Children, „Journal of Marriage and Family”, nr 76, 300-318.

Myers J.E., 1988, The Mid/Late Life Generation Gap: Adult Children with Aging Parents, „Journal of Counseling \& Development", vol. 66, nr 7, 331-335. 
Ogg J., Renaut S., 2006, The support of parents in old age by those born during 1945-1954: a European perspective, „Ageing \& Society”, nr 26(5), 723-43.

Pączkowska M., 2002, Samopomoc, pomoc i opieka społeczna, [w:] J. Halik (red.), Starzy ludzie $w$ Polsce. Społeczne i zdrowotne skutki starzenia się społeczeństwa (s. 61-70), Instytut Spraw Publicznych, Warszawa.

Rossi, A.S., Rossi, P.H., 1990, Of human bonding: Parent-child relations over the life course. New York: Aldine de Gruyter.

Saraceno Ch., 2008, Introduction: Intergenerational relations in families - a micro-macro perspective, [w:] Ch. Saraceno (red.), Families, Ageing and Social Policy: Intergenerational Solidarity in European Welfare States (Globalization and Welfare) (s. 1-19), Edward Elgar, Cheltenham.

Shemmings D., 2006, Using adult attachment theory to differentiate adult children's internal working models of later life filial relationships, „Journal of Aging Studies”, $\mathrm{nr}$ 20, 177-191.

Sherman S.R., Ward R.A., LaGory M., 1988, Women as Caregivers of the Elderly: Instrumental and Expressive Support, „Social Work”, vol. 33, nr 2, 164-167.

Spitze G., Logan J.R., 1991, Sibling Structure and Intergenerational Relations, „Journal of Marriage and Family", vol. 53, nr 4, 871-884.

Stuifbergen M.C., van Delden J.J.M., Dykstra P.A., 2008, The implications of today's family structures for support giving to older parents, „Ageing and Society” nr 28: 413-434.

Szczerbińska K., 2006, Korzystanie osób starszych ze świadczeń medycznych i opiekuńczych w Polsce, [w:] Szczerbińska K. (red.), Dostępność opieki zdrowotnej i pomocy społecznej dla osób starszych w Polsce (s. 45-54), Wydawnictwo Uniwersytetu Jagiellońskiego, Kraków.

Szukalski P., 2002, Przeplywy międzypokoleniowe i ich kontekst demograficzny, Wydawnictwo Uniwersytetu Łódzkiego, Łódź.

Szukalski P., 2008, Relacje międzypokoleniowe z demograficznego punktu widzenia $w$ starzejacym się spoteczeństwie polskim, [w:] Rządowa Rada Ludnościowa, Sytuacja demograficzna Polski. Raport 2007-2008 (s. 206-223), Zakład Wydawnictw Statystycznych GUS, Warszawa.

Szweda-Lewandowska Z., 2014. Status rodzinny i nieformalne nierodzinne sieci wsparcia a zamieszkiwanie w instytucjach, „Studia Demograficzne”, nr 2(166), 79-95.

Van Gaalen R.I., Dykstra P.A., 2006, Solidarity and conflict between adult children and parents: A latent class analysis, „Journal of Marriage and Family”, nr 68, 947-960.

Vaupel J.W., von Kistowski K.G., 2008, Living longer in an ageing Europe: a challenge for individuals and societies, „European View”, nr 7(2): 255-263.

Vaupel J.W., 2010, Biodemography of human ageing, „Nature”, nr 464: 536-542.

Wijckmans B., Van Bavel J., 2010, Divorce and intergenerational family obligations: Past research and current patterns in the Netherlands, Interface Demography Working Paper 2010-1, Brussels, Free University.

Wizner B., Skalska A., Klich-Rączka A., Piotrowicz K., Grodzicki T., 2012, Ocena stanu funkcjonalnego u osób w starszym wieku, [w:] M. Mossakowska, A. Więcek, P. Błędowski (red.), Aspekty medyczne, psychologiczne, socjologiczne i ekonomiczne starzenia się ludzi w Polsce (s. 81-94), Termedia Wydawnictwo Medyczne, Poznań.

Wolf D.A., Ballal S.S., 2006, Family support for older people in an era of demographic change and policy constraints, ,Ageing and Society”, nr 26, 693-706.

Wooldridge J. M., 2006, Introductory econometrics: a modern approach, Thomson/South-Western.

Wóycicka I., 2009, Model opieki w Polsce, [w:] I.E. Kotowska (red.), Strukturalne i kulturowe uwarunkowania aktywności zawodowej kobiet w Polsce (s. 99-118), Wydawnictwo Scholar, Warszawa. 


\title{
DETERMINANTS OF CAREGIVING \\ FOR ELDERLY PARENTS IN POLAND \\ BASED ON THE GGS-PL SURVEY
}

\begin{abstract}
The main aim of the paper was to analyse determinants of care for elderly parents provided by adult children in Poland. The data were from the first wave of the Polish Generations and Gender Survey (GGS-PL) carried out in 2010 and 2011. The logistic regression model with the dependent binary variable describing the fact of providing care to elderly mother or father has been applied. The obtained results are mostly in line with those described in the literature on this topic. Generally the probability of giving care to elderly parents increases with respondent's age. Women have higher chances of providing care to older mother or father than men do. Persons better educated (with secondary or higher level of education) are characterized by higher probability of caring for elderly parents. Parameters estimates for several variables such as place of residence, living arrangements, employment status and health status were statistically insignificant. As it would have been anticipated health status of a parent significantly increases the probability of providing care to a mother or a father. Moreover, the better the relationship between children and parents, the higher chances of taking care of older parents. In addition, the more respondents agreed with the opinion of responsibility of children for care for elderly parents, the higher the risk of providing an instrumental help by them was.
\end{abstract}

Keywords: elderly care, sandwich generations, population ageing, intergenerational relations 